
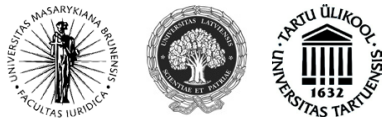

ISSN 2029-2244 (online)

SOCIALINIŲ MOKSLŲ STUDIJOS

SOCIETAL STUDIES

$2014,6(3)$, p. 648-660.

\title{
DĖMENI BENDR- TURINTYS ASMENŲ PAVADINIMAI IR JŲ DARYBOS YPATUMAI ADMINISTRACINĖJE KALBOJE
}

\author{
Laima Pečkuvienè \\ Mykolo Romerio universiteto Politikos ir vadybos fakulteto \\ Filosofijos ir humanistikos institutas \\ Ateities g. 20, LT-08303 Vilnius, Lietuva \\ Tel. +370 52714617 \\ El. paštas: laima.peckuviene@gmail.com
}

Iteikta $2014 \mathrm{~m}$. kovo $21 \mathrm{~d}$., parengta spausdinti $2015 \mathrm{~m}$. sausio $28 \mathrm{~d}$.

doi:10.13165/SMS-14-6-3-12

Anotacija. Straipsnyje analizuojami Lietuvos Respublikos teisès kodeksuose ir kodeksu komentaruose vartojami su demeniu bendr-sudaryti asmenu pavadinimai. Šiu tekstu analize leidžia daryti išvadą, kad tokị dèmenị turintys administracinès kalbos terminai yra sudaryti skirtingai ir ne visais atvejais ju daryba atitinka bendrinès kalbos žodžiu darybos reikalavimus. Pavyzdžiui, terminai bendraturtis ir bendraskolis sudaryti taisyklingai, o bendrasavininkis ir bendravykdytojas turi bendrinès kalbos düriniams nebūdingus antruosius demenis.

Darant sudurtinius asmenu pavadinimus, reikia laikytis bendrinès kalbos düriniu darybos tradicijos, kuri rodo, kad sudurtinius žodžius lietuvių kalboje kur kas labiau iprasta daryti iš paprastuju žodžiu nei iš vediniu ar dūrinių. Net ir tais atvejais, kai pamatiniai dèmenys turi priesagas, daugeliu atveju ju nelieka pasidarytame dūrinyje.

Taip pat svarbu, kad tam tikros srities kalboje vartojami dūriniai turètu bendrinès kalbos dūriniams büdingas reikšmes. Daryba ir reikšmè yra glaudžiai tarpusavyje susije dalykai, todèl vienu ar kitu darybos büdu sudarytas terminas turi būti verti-

Socialinių mokslų studijos / Societal Studies

(C) Mykolo Romerio universitetas, 2014

(C) Mykolas Romeris University, 2014
ISSN 2029-2244 (online)

http://www.mruni.eu/lt/mokslo_darbai/SMS/ http://www.mruni.eu/en/mokslo_darbai/SMS/ 
namas remiantis šiais kriterijais. Apeiti kodifikuotas kalbos normas galima tada, kai naudojantis esamais kalbos ištekliais nepavyksta sudaryti specialybès kalbai reikalingo termino.

Vertinant administracinius terminus bendrinès kalbos normos aspektu bütina skirti, kada ju darybos nukrypimai nuo bendrinés kalbos normu yra neišvengiama bütinybè, reikalinga vartojimo srities poreikiams patenkinti, o kada taisyklingos kalbos reikalavimu nesilaikymas yra elementari klaida. Tai reikalinga norint neisileisti $i$ administracinę kalbą nenorminès darybos žodžių.

Reikšminiai žodžiai: bendrinė kalba, administracinė kalba, vediniai, dūriniai (sudurtiniai žodžiai), žodžių dèmenys.

\section{Itvadas}

Lietuvių bendrinės kalbos kūrimo ir norminimo istorija rodo, kad terminų taisyklingumo klausimai visais laikais buvo kalbininkų dėmesio centre. Lietuvių kalbininkų indèlị kuriant ịvairių sričių terminus aptaria Stasys Keinys knygoje „Lietuvių terminologijos raida"1. Analizuodamas lietuvių terminijos raidos dalykus ir rašydamas apie kalbos norminimo darbą dirbusius mokslo žmones, knygos autorius iškelia ypatingą Jono Jablonskio vaidmenį: „Iki Jablonskio dažnas lietuviškai rašęs veikèjas nebuvo kaip reikiant supratęs lietuvių gramatinès sandaros ir suvokęs jos žodžių darybos polinkių. Tad daugybė naujų žodžių buvo pamorfemiui išversti iš kitų kalbų“2. Lietuvių literatūrinès kalbos kūrèjas Jonas Jablonskis ị terminų kūrimą žiūrèjo kitaip. Pagrindiniu terminų kūrimo šaltiniu jis laikẻ liaudies kalbą. 1913 m. „Lietuvių Tautai“ parašytoje studijoje apie Kazimiero Jauniaus gramatiką Jonas Jablonskis rašė: „<..> ir terminai, naujai daromi, turi būti dirbami taip, kaip yra žmonių dirbami paprastieji kalbos žodžiai“"3. Tai reiškia, kad darant terminus turi būti laikomasi darybos tradicijos, kuri eina iš savosios kalbos, o ne iš svetimų kalbų perimama.

Aldonas Pupkis monografijoje „Kalbos kultūros studijos“ kalbėdamas apie terminų atsiradimo būdus, kurių mes turime tris - savų žodžių terminizavimas, naujadarų kūrimas ir skolinimasis iš kitų kalbų - taip pat pabrěžia, kad norint išvengti terminų darybos nenuoseklumo „<...> būtina jausti mūsų žodžių darybos polinkius ir suvokti, kur tų polinkių nepaisoma ir nusižengiama elementariems taisyklingumo reikalavimams “4

Kazimieras Gaivenis knygoje „Lietuvių terminologija: teorijos ir tvarkybos metmenys " ${ }^{\text {5 }}$ aptaria svarbiausias terminų ypatybes ir terminams keliamus reikalavi-

1 Keinys, S. Lietuviu terminologijos raida. Vilnius: Lietuvių kalbos instituto leidykla, 2012.

2 Ibid., p. 46.

3 Jablonskio Raštai. T. 3. Kaunas, 1934, p. 37 in Keinys, S. Lietuvių terminologijos raida. Vilnius: Lietuvių kalbos instituto leidykla, 2012, p. 46.

4 Pupkis, A. Kalbos kultūros studijos. Vilnius: Gimtasis žodis, 2005, p. 262.

5 Gaivenis, K. Lietuviu terminologija: teorijos ir tvarkybos metmenys. Vilnius: Lietuvių kalbos instituto leidykla, 2002. 
mus. Vienu svarbiausių terminų kalbinių reikalavimų yra laikomas terminų taisyklingumas - t. y. „<...> sutikimas su kirčiavimo, rašybos, gramatikos, žodžių darybos, gramatinimo ir vartojimo taisyklemis"6. Terminas turi atitikti visus taisyklingai kalbai keliamus reikalavimus. Pateikdamas terminų nesutikimo su kalbos normomis atvejų, kurie atsiranda dèl netaisyklingo kirčiavimo (vietoj remòntas sukirčiuojama rèmontas), netaisyklingos darybos (sutrauktinis daiktavardis vyrinžinierius vartojamas vietoj junginio vyresnysis (vyriausiasis) inžinierius), netaisyklingos rašybos ( $g y$ dytojas-chirurgas vietoj gydytojas chirurgas) netaisyklingo gramatinimo (vietoj formos ekslibris geriau vartoti ekslibrisas), Kazimieras Gaivenis atkreipia demesį, kad pasakymas „netaisyklingas terminas“ terminų tvarkybos praktikoje dažniausiai vartojamas kalbant apie netipiškos darybos terminus?.

Taigi netaisyklingu terminu laikomas toks terminas, kurio daryba nèra būdinga kalbos žodžių darybai. Knygoje nurodomos dažniausios netaisyklingos darybos terminų atsiradimo priežastys. Jos yra tokios: „netikslus priešdèlio, priesagos, galūnès, sando ar pamatinio žodžio pasirinkimas, nulemtas kitų kalbų žodžių struktūros kopijavimo. $<\ldots>$ netikslus darybos tipo ar kategorijos pasirinkimas, nulemtas pseudoanalogijos principo taikymo"8.

Kadangi specialybės kalbos pagrindą sudaro atitinkamos srities terminai, tai terminų taisyklingumas laikytinas vienu svarbiausių specialybės kalbos taisyklingumo rodiklių.

Specialybės terminų darybai keliami taisyklingos bendrinès kalbos žodžių darybos reikalavimai ir bet kuriuo darybos būdu sudaryti specialybės kalboje vartojami terminai (kaip ir kiti specialybės kalbos žodžiai) turi būti vertinami pagal jų sutikimą su bendrinès kalbos žodžių daryba. Administracinių tekstų analizè leidžia daryti išvadą, kad terminų sudarymo klausimai yra aktualūs administracinei kalbai.

Taisyklingumo reikalavimai vienodai svarbūs ir vienažodžiams terminams, ir sudètinių terminų dèmenims. Dalis sudètinių administracinių terminų yra sudaryta su priesagos $-i n i s,-\dot{e}$ vediniais. Tokie vediniai vartojami rūšiniam požymiui reikšti, pavyzdžiui: įstatyminiai (: įstatymas) ịpédiniai, ìstatyminiai atstovai. Tačiau šių terminų dèmuo ịstatyminis nesuderinamas su taisyklingos būdvardžiu darybos reikalavimais, nes bendrinejje kalboje būdvardžiai su priesaga -inis, $-\dot{e}$ nèra daromi iš veiksmažodinès kilmės daiktavardžių, kurie patys yra priesagų vediniai. Dèl šios priežasties iš veiksmažodžio padarytas daiktavardis ịstatymas negali būti pasirenkamas pamatiniu būdvardžio žodžiu. Su tokiais būdvardžiais sudarytų terminų administracinè kalba turètų atsisakyti. Ypač nedera kartu vartoti netaisyklingai ir taisyklingai sudarytu terminų: ¡statyminiai ipediniai ir ipédiniai pagal ịstatyma, ìstatyminiai atstovai ir atstovai pagal įtatyma (plg. atstovai pagal pavedima) ${ }^{9}$.

6 Gaivenis, K., supra note 5, p.36.

$7 \quad$ Ibid., p. 37.

$8 \quad$ Ibid.

9 Palyginkime: $\langle\ldots\rangle$ ju interesams turi teise atstovauti ju įstatyminiai atstova (tèvai, įtéviai, globotojai, rūpintojai) (Lietuvos Respublikos administracinių teisès pažeidimų kodekso 
Visais įmanomais atvejais specialybès kalba turi laikytis bendrinei kalbai priimtinos žodžių darybos. Tik tais atvejais, kai tenkindama specifinius vartojimo srities poreikius ji negali išsiversti naudodamasi tradiciniais darybos būdais, ieškoma kitokios raiškos. Bendrinè kalba turi pripažinti, kad be tam tikrų kompromisų specialybès kalbos terminų daryba neįmanoma, tačiau būtina siekti, kad nenorminès raiškos atvejų nesirastų ten, kur kalbos galimybès leidžia jų išvengti. Išimtys neturi tapti nor$\mathrm{ma}^{10}$.

Vienu ar kitu darybos būdu sudaryti žodžiai bendrineje kalboje turi tam tikras reikšmes. Tas reikšmes turi perimti ir specialybès kalboje vartojami analogišku darybos būdu sudaryti žodžiai. Tačiau kai kuriais atvejais vienos ar kitos srities kalboje gali atsirasti žodžių, turinčių ir kitokias reikšmes, nei ịprastai tokie žodžiai turi bendrineje kalboje. Administracinẻ kalba yra suteikusi naujas reikšmes priesagų -ejjas, - $a$ ir -tojas, - $a$ vediniams. Čia tokiais vediniais pavadinami ne tik asmenys, bet ir ístaigos ir įmonès (įmonè gali būti siuntos gavèja, elektros gamintoja), o bendrineje kalboje šių priesagų vediniais yra žymimi asmenys pagal atsitiktinai atliekamą ar nuolatinị veiksmą, pvz.: gavejjas, -a, teiséjas, -a, pataikautojas, -a, gydytojas, $-a^{11}$.

Administracineje kalboje asmenims pavadinti vartojami su demeniu bendr-sudaryti sudurtiniai žodžiai (dūriniai) bendraieškis, bendraieškovis, bendraatsakovis, bendravykdytojas, bendraautoris, bendrakaltis, bendraturtis, bendrasavininkis. $\mathrm{Pa}-$ vyzdžiui: Taikos sutarčiai sudaryti, atsisakyti ieškinio ar ieškini pripažinti būtinas visu bendrininku (bendraieškiu arba bendraatsakoviü) sutikimas <... $>^{12}$; Pats vaikas, dèl kurio gyvenamosios vietos sprendžiama, šios kategorijos bylose nèra dalyvaujantis byloje asmuo, jis negali būti bendraieškovis, bendraatsakovis ar trečiasis asmuo ${ }^{13}$. Tokie sudurtiniai terminai turi skirtingus antruosius demenis: vienais atvejais dūriniai yra išlaikę pamatinių žodžių priesagas, kitais atvejais dūriniai sudaryti be

274 str.); <...> teises ir ịstatymų saugomus interesus gina teisme jų atstovai pagal istatyma atitinkamai ju tèvai, ịtèviai, globèjai (Lietuvos Respublikos civilinio proceso kodekso 38 str. 4 d.).

10 Bendrinei kalbai neịprastu būdu sudarytą būdvardị turi terminas besąlyginis sandoris. Besąlyginis yra mišrios darybos priešdèlinis priesaginis vedinys, padarytas iš prielinksninès konstrukcijos be sqlygų. Bendrinejje kalboje iš prielinksnio be konstrukcijų iprasčiau daryti ne mišraus tipo priešdèlinius priesaginius vedinius, o priešdèlio be-ir galūnès $-i s,-\dot{e}$ vedinius, pavyzdžiui: begarsis, -é, belapis, $-\dot{e}$, beskonis, $-\dot{e}$. Lietuvių kalboje yra tik keli priešdèli be- ir priesagą -inis, $-\dot{e}$ turintys būdvardžiai: begalinis (begaliné tiesé, begaliné aibè) ir besąlyginis (besalyginé kapituliacija).

Mišraus tipo priešdèliniai priesaginiai vediniai bendrineje kalboje sudaromi iš kitokių prielinksninių konstrukcijų: įcentrine (: $j$ centra) jèga, povandeninis (: po vandeniu) laivas, tarpmiestinis (: tarp miestu) traukinys ir t. t.

11 Dabartinès lietuviu kalbos gramatika. Ambrazas, V., et al. Ketvirtoji pataisyta laida. Vilnius: Mokslo ir enciklopedijų leidybos institutas, 2005, p. 104, p. 106.

12 Lietuvos Respublikos civilinio proceso kodeksas. Vilnius: Registrų centras, 2012, 44 str.

13 [interaktyvus]. [žiūrèta 2014-02-24]. <http://www.teisesgidas.lt/modules/paieska/lat.php?id= $26320>$. 
jų. Kartais ta pačia reikšme pavartojami keli terminai, pavyzdžiui, bendraieškis ir bendraieškovis, bendraturtis ir bendrasavininkis. Terminų variantai nèra pageidaujamas dalykas jokios srities kalboje.

Administracinių tekstų analizė leidžia daryti išvadą, kad terminų sudarymo ir vartojimo klausimai yra aktualūs administracinei kalbai, todèl ir buvo atliktas šis tyrimas.

Šio tyrimo tikslas - ịvertinti dabartinèje administracinèje kalboje vartojamus dèmeni bendr- turinčius sudurtinius asmenų pavadinimus bendrinès kalbos normos aspektu. Taip pat svarbu išsiaiškinti priežastis, del kurių administracinejje kalboje atsiranda skirtingai sudarytų tokị dėmenị turinčių terminų. Visa tai padètų išvengti netinkamos darybos žodžiu administraciniuose tekstuose, o tai yra svarbu siekiant šios srities kalbos taisyklingumo.

Tyrimo objektas - Lietuvos Respublikos teisès kodeksuose ir jų komentaruose vartojami su dèmeniu bendr-sudaryti asmenų pavadinimai.

Atliekant tyrimą taikyti aprašomasis ir analitinis metodai.

\section{Sudurtinių daiktavardžių daryba ir dèmenị bendr-turintys administraciniai terminai}

Sudurtinių daiktavardžių dèmuo bendr-atsiranda iš būdvardžio bendras ar būdvardinio prieveiksmio bendrai. Apie asmenų pavadinimų, turinčių tokị dèmenį, taisyklingumą kalbos praktikai skirtuose darbuose rašoma jau ne vieną dešimtmetį. Tai rodo, kad tokių sudurtinių daiktavardžių (dūrinių) daryba nèra iki galo perprasta ir tai yra pagrindiné priežastis, dèl kurios administracinejje kalboje nepavyksta išvengti ydingai sudarytų žodžių ir tam tikrais atvejais nevartoti lygiagrečiai norminių ir nenorminių tokią pačią reikšmę turinčių dūrinių.

Norint atskirti tinkamos darybos dūrinius nuo sudarytų netinkamai reikia būti susipažinusiam su bendrinès lietuvių kalbos sudurtinių daiktavardžių darybos reikalavimais. Aptariant bendrinès kalbos žodžių darybos būdus „Dabartinès lietuvių kalbos gramatikoje“ rašoma, kad mūsų kalboje sudurtinius žodžius kur kas labiau ipprasta daryti iš paprastųjų žodžių negu iš vedinių ir dūrinių ${ }^{14}$. Vadinasi, priesaginius dèmenis turinčių dūrinių bendrinèje kalboje yra mažiau nei dūrinių, kurie sudaryti iš paprastųjų žodžių. Pavyzdžiui, iš dviejų daiktavardžių daromų dūrinių, „kurių bent vienas sandas atsiradęs iš priesaginio daiktavardžio, pasitaiko retokai, pvz.: dirvonvieté, puskailiniai, šienvežis "15. Priesagas turi dūrinio dirvonviete (: dirvonas + vieta) pirmasis dèmuo ir dūrinių puskailiniai (: pusè + kailiniai) ir šienvežis (: šienas + vežimas) antrieji dėmenys.

Kaip jau buvo rašyta, kalbai ịprastesni priesagų neturintys dūriniai. Todèl iš daiktavardžių sudarytų sudurtinių daiktavardžių „sandai kartais neturi priesagų net 
ir tokiais atvejais, kai darybiškai santykiauja su priesaginiais daiktavardžiais, pvz.: vainiklapis „(bot.) žiedo vainikèlio lapelis“, virbgalys „virbalo galas“, žiedadulkè „(bot.) žiedo dulkelè “16.

Sudurtinių daiktavardžių iš dviejų daiktavardžių ir iš būdvardžio ir daiktavardžio daryba turi panašumų. Analizuojant iš būdvardžio ir daiktavardžio sudaromų daiktavardžių darybą „Dabartinès lietuvių kalbos gramatikoje“ teigiama, kad dauguma tokių dūrinių sudaryti iš tokių pamatinių žodžių, kurių kamienai lygūs šaknims. Taigi ir jiems, kaip ir didžiajai daliai dūrinių, sudarytų iš dviejų daiktavardžių, nebūdingi priesaginiai dèmenys, nes „ilgesnes ir aiškiai jaučiamas priesagas turintys žodžiai retai kada virsta šios rūšies dūrinių sandais"17. Gramatikoje pateikiama tokių pavyzdžių: garbanotplaukis, - $\dot{e}$, gelžinsnapis, sunkvežimis, bendraatsakovis, $-\dot{e}$ ir kt. Mums svarbu, kad tarp pateiktų retesnès darybos pavyzdžių yra vienas dèmenị bendr-turintis dūrinys bendraatsakovis, $-\dot{e}$. Antrasis šio sudurtinio daiktavardžio dèmuo yra su priesaga sudarytas veiksmažodinès kilmès vedinys atsakovas, -è (keičiasi pamatinių žodžių galūnès ir dūriniai turi galūnes $-i s,-\dot{e}$ ).

Terminas bendraatsakovis, $-\dot{e}$ vartojamas administracineje kalboje: „<...> ir paskleisty duomeny autorius, ir visuomenés informavimo priemone tokiose bylose turètu büti traukiami kaip bendraatsakoviai <...>; Itraukti i byla kaip bendraatsakovius tiek autoriu, tiek visuomenès informavimo priemonę svarbu del to, kad <...> "18 ; Juridinio asmens dalyvis <...> privalo kreiptis i kitus juridinio asmens dalyvius ir siūlyti būti bendraatsakoviais ${ }^{19}$; <...> bütinas visu bendrininkų (bendraieškiu arba bendraatsakoviu) sutikimas $<\ldots>^{20}$.

Turime ir dar vieną su dèmeniu bendr-sudarytą administracinės kalbos terminą bendraieškis: „<...> šie asmenys <...> ịtraukiami dalyvauti procese trečiaisiais asmenimis, nepareiškiančiais savarankišku reikalavimų, arba bendraieškiais “ ${ }^{21} ;<\ldots>$ privalo kreiptis ị kitus juridinio asmens dalyvius siūlydamas

tapti bendraieškiais ${ }^{22}$. Dūrinys bendraieškis sudarytas kitaip negu bendraatsakovis: jis neturi priesaginio daiktavardinio dèmens.

Lyginant bendraieškị su bendraatsakoviu kyla klausimas, kodèl atsiranda toks terminų darybos skirtumas? Ar tas skirtumas pagrịstas būtinybe? Jeigu turime bendraatsakovį, tai prašyte prašosi, kad būtų ir analogiškai sudarytas bendraieškovis. Antrasis šio dūrinio dėmuo, kaip ir vartojamo termino bendraatsakovis dèmuo, taip pat būtų iš veiksmažodžio padarytas priesagos -ovas, - $\dot{e}$ vedinys ieškovas. Arba

16 Dabartinés lietuviu kalbos gramatika, supra note 11.

17 Ibid., p. 155.

18 Mikelènas, V., et al. Lietuvos Respublikos civilinio kodekso komentaras. Antroji knyga. Vilnius: Justitia, 2002, p. 71.

19 Lietuvos Respublikos civilinis kodeksas.Vilnius: Registrų centras, 2012, 2.123 str. 2 d.

20 Lietuvos Respublikos civilinio proceso kodeksas, supra note 12, 44 str.

21 Ibid., 49 str. $3 \mathrm{~d}$.

22 Lietuvos Respublikos civilinis kodeksas, supra note 19, 2.115 str. 4 d. 
atvirkščiai: vartojant priesaginio dėmens neturintị dūrinị bendraieškis reikètų vartoti ir tokiu pačiu būdu sudarytą terminą bendraatsakis. Kuris variantas bendrinei kalbai priimtinesnis?

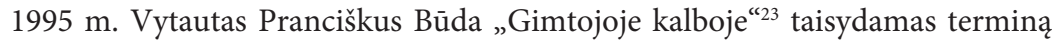
bendraatsakovas, kuris negali būti vartojamas dèl galūnès -as (bendrinèje kalboje dèmenị bendr- turinčių sudurtinių žodžių galūnè turi būti $-i s,-\dot{e}$, pvz.: bendradarbis, $-\dot{e}$, bendrašonis ir t. t.), rašè, kad ir net ir pataisius galūnę bendraatsakovis vis tiek negali būti vartojamas kalboje. To priežastis - ydinga žodžio reikšmè.

Turime neužmiršti, kad vartojant vienu ar kitu būdu sudarytus žodžius būtina atsižvelgti ị tai, kokias reikšmes tokios darybos žodžiai turi bendrinèje kalboje. Tik išimtiniais atvejais pasidaryti žodžiai tam tikros srities kalboje gali būti vartojami kita reikšme nei tokiems dariniams būdinga bendrinejje kalboje ${ }^{24}$.

Kalbant apie bendraatsakovio vartojimą „Gimtosios kalbos“ straipsnyje primenama, kad dūrinių, sudarytų su dèmeniu bendr-, reikšmè bendrineje kalboje yra tokia: „tas, kas turi su kitu (kitais) ką bendra“: bendraturtis, $-\dot{e}$ (: bendras + turtas), bendramokslis, $-\dot{e}(:$ bendras + mokslas $)$, bendravardis, $-\dot{e}(:$ bendras + vardas $)$, bendradarbis, $-\dot{e}$ (: bendras + darbas) arba „tas, kas bendra daugeliui“: bendrabutis. Taigi ir bendraatsakovis turètų reikšti „atsakovą, bendrą kelioms byloms“. Tačiau terminas vartojamas kita reikšme: juo administracineje kalboje yra vadinami keli vienos bylos atsakovai. Ydingos reikšmès dūrinys pasiūlytas keisti bendraatsakiu (: bendrai + atsako). Tokio termino pirmasis dèmuo yra iš būdvardžio bendras padarytas prieveiksmis, o antruoju dèmeniu eina veiksmažodis. Savo siūlymą Vytautas Pranciškus Būda parèmè „Kanceliarinès kalbos patarimuose“ pateiktu bendravykdžiu ${ }^{25}$ (: bendrai + vykdo), taip pat bendrinejje kalboje vartojamais veiksmažodinį dèmenị turinčiais dūriniais barzdaskutys (: barzda + skuta), kraujoplüdis (: kraujas + plüdo).

Būda, V. P. Ar vartotinas bendraatsakovas? Gimtoji kalba. 1995, 1: 18-19.

24 Tokiu pavyzdžiu gali būti administracinèje kalboje vartojamas priesaginiu būdu sudarytas terminas pasienietis. Juo asmuo pavadinamas pagal profesiją, tačiau bendrineje kalboje su priesaga -ietis, - $\dot{e}$ sudaryti vediniai turi kitokią reikšmę. „Dabartinès lietuvių kalbos gramatikoje“ nurodoma, kad bendrineje kalboje su tokia priesaga sudarytais žodžiais asmenys pavadinami pagal jų kilimo bei gyvenamąją vietą (miestietis, -é, kaimietis, -è), o asmenų pavadinimams pagal profesiją ar atliekamą veiksmą daryti yra vartojamos kitokios priesagos. Iš daiktavardžių tokie vedinai daromi su priesagomis -ininkas, $-\dot{e}$ (durininkas, $-\dot{e})$, -istas (germanistas, $-\dot{e})$, -orius, $-\dot{e}$ (ambasadorius, $-\dot{e})$ ir kt. Iš veiksmažodžių - su priesagomis -tojas, -a (gydytojas, $-a$ ), -èjas, $-a$ (gavéjas, $-a),-i k a s,-\dot{e}($ nešikas, $-\dot{e}),-l y s,-\dot{e}($ pirklys, $-\dot{e})$ ir t. t.

Skirdami išimtinius vartojimo atvejus ir siekdami bendrinei kalbai priimtinesnès vartosenos, neturime ị kalbą įsileisti lengvai pataisomų priesagos -ietis, $-\dot{e}$ nenorminių vedinių, pavyzdžiui, darbietis (vietoj Darbo partijos narys), saugumietis (vietoj Valstybés saugumo departamento pareigūnas, saugumo struktūru pareigūnas), partietis ir bendrapartietis (vietoj tos pačios partijos narys, vienos partijos narys) ir pan.

25 Kanceliarinès kalbos patarimai. Parengė Kniūkšta, P. Vilnius: Mokslo ir enciklopedijų leidykla, 1993, p. 40. 
Analogą turime ir administracinèje kalboje. Tai anksčiau minètas administracinis terminas bendraieškis, kurio antrasis dèmuo sudarytas iš veiksmažodžio. Iš būdvardžio ar būdvardinès kilmès prieveiksmio ir veiksmažodžio atsiradusių sudurtinių daiktavardžių (asmenų, gyvulių, negyvų daiktų ir kitokių pavadinimų) turime bendrinèje kalboje. „Dabartinès lietuvių kalbos gramatikoje“ pateikiama tokių dūrinių pavyzdžių:

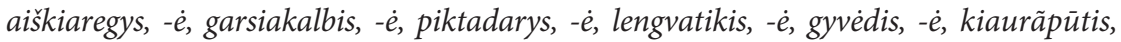
garsiãkalbis, plikšala, šlãpdraba ${ }^{26}$. Administracinè kalba taip pat galètu pasinaudoti tokiu asmenų pavadinimų darybos būdu.

Siūlomo vartoti bendraatsakio ir jau vartojamo bendraieškio darybą remia ir jau minètas 1993 m. išleistuose „Kanceliarinès kalbos patarimuose“ pateiktas dūrinys bendravykdis. Jis buvo siūlytas vietoj termino bendravykdytojas. Kartu buvo pasiūlytas ir kitas galimas bendravykdytojo pakaitas - vykdymo bendrininkas. Tačiau pataisytuose ir papildytuose vèlesniuose „Kanceliarinès kalbos patarimų“ leidimuose apie terminą bendravykdytojas jau nekalbama.

Administracinejje kalboje bendravykdytojas vartojamas, pavyzdžiui: Jeigu nusikalstama veikg padare keli asmenys kartu, tai kiekvienas iš ju laikomas vykdytoju (bendravykdytoju ${ }^{27} ;<\ldots>$ jie atsako kaip bendravykdytojai tik pagal komentuojamo straipsnio 1 dali $^{28}$. Šio termino antrasis dèmuo -veiksmažodinis daiktavardis vykdytojas - turi ryškią priesagą, o bendrineje kalboje, kaip jau buvo rašyta anksčiau, sudurtinius žodžius ịprasčiau yra sudaryti iš priesagų neturinčių sandų. I tai derètų atkreipti dèmesị administracinès kalbos kūrèjams ir paieškoti galimybių vietoj termino bendravykdytojas vartoti bendrinei kalbą priimtiną atitikmenį. Kodèl tokiu pakaitu negalètų būti bendravykdis? Juo labiau kad administracinèje kalboje yra sektinas pavyzdys - bendraieškis.

Terminai bendraatsakovis, bendraieškovis ir bendravykdytojas vertinami kaip netaisyklingi (prie jų pažymėta nts., t. y. netaisyklingas) 1992 m. išleistuose „Terminologijos taisymuose“. Jokių išlygų čia nedaroma anksčiau aptartam „Dabartinès lietuviu kalbos gramatikoje“ teikiamam bendraatsakoviui. Terminai pataisyti taip: bendraatsakovis, $-\dot{e}$ (= atsakomybès bendrininkas, $-\dot{e})$, bendraieškovis (= ieškinio bendrininkas, $-\dot{e})$, bendravykdytojas, -a (=vykdymo bendrininkas, $-\dot{e}$, bendravỹkdis, $-\dot{e})^{29}$. Matome, kad siūlant taisinių pakaitus pirmenybė teikiama ne vienažodžiams, bet dvižodžiams terminams. Administraciniuose tekstuose vartojamų terminų analizė leidžia daryti išvadą, kad i terminologų pasiūlytus taisymus nebuvo atsižvelgta. Viena iš priežasčių gali būti ir tokia: vienažodžiai terminai yra patogesni, todèl net ir abejotinos darybos atveju jie pasirenkami vartoti vietoj dviejų žodžių junginio.

26 Dabartinés lietuviu kalbos gramatika, supra note 11, p. 164-165.

27 Lietuvos Respublikos baudžiamasis kodeksas. Vilnius: Mūsų Saulužè, 2012, 24 str. 3 d.

28 Abramavičius, A., et al. Lietuvos Respublikos baudžiamojo kodekso komentaras. Antra knyga. Vilnius: Teisinès informacijos centras, 2004, p. 399. 


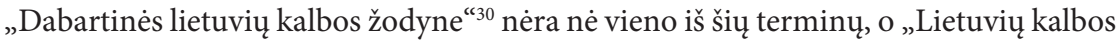
žodyne ${ }^{{ }^{\prime 31} 1}$ pateikiamas ir bendraatsakovis, ir bendraieškovis. Nèra tik bendravykdytojo.

Teisès kodeksuose yra vartojama su daiktavardžiu bendrininkas sudarytų junginių, pavyzdžiui: Bendrininkavimas ir bendrininku rū šys $s^{32}$; Bendrininkavimo formos yra bendrininku grupé, organizuota grupe, nusikalstamas susivienijimas ${ }^{33}$. Tačiau nei atsakomybès bendrininko, nei ieškinio ar vykdymo bendrininko rasti nepavyko.

Skirtingais terminais administracineje kalboje pavadinami bendro turto turintys asmenys. Pavyzdžiui, „Civiliniame kodekse“ ir „Baudžiamojo proceso kodekse“ vartojamas terminas bendraturtis: Bendraturčiu gali büti kiekvienas asmuo, galintis büti nuosavybès teisiniu santykiu subjektu ${ }^{34}$; Nutarimo $<\ldots>$ nuorašas įteikiamas turto $<\ldots>$ savininkui (bendraturčiams) ${ }^{35}$. Toks terminas yra „Lietuvių kalbos žodyne". Bendraturtis turi su dèmeniu bendr-sudarytiems dūriniams būdingą reikšmę: taip pavadinamas asmuo, su kuriuo turima bendro turto. Tačiau komentuojant anksčiau cituotą „Baudžiamojo proceso kodekso“ straipsnị „Baudžiamojo proceso kodekso komentare" vartojamas tokios reikšmès neturintis ir kitaip sudarytas terminas: <...> ipareigoja pareigūną nutarima dèl turto apribojimo nedelsiant paskelbti tokio turo savininkui ir bendrasavininkiams ${ }^{36}$.

Kaip ir anksčiau analizuotas bendraatsakovis, bendrasavininkis nepriimtinas vartoti dèl ydingos reikšmès. Jonas Klimavičius žurnale „Gimtoji kalba" ${ }^{{ }^{37} 7}$ primindamas, kad bendrasavininkio nèra norminamojo „Dabartinès lietuvių kalbos žodyno“ trečiame, ketvirtame ir penktame leidimuose, todèl ir jo vartoti netinka, atkreipè dèmesi i tai, kad „nuosavybe - ne tik turtas, todèl ne visada tiks bendraturtis" ${ }^{\prime 38}$. Kadangi bendroji nuosavybė gali būti dviejų rūšių - jungtinè ir dalinè, tai reikia vartoti ir atitinkamus terminus asmenims, turintiems vienos ar kitos rūšies nuosavybę, pavadinti. Tai galètų būti jungtinés bendrosios nuosavybès dalininkas ir dalinés bendrosios nuosavybès turètojas. Administracinè kalba tokio skirtumo nedaro ir tiek bendrosios dalinès, tiek bendrosios jungtinès nuosavybès turètojus vadina vienu terminu: Bendraturčiu teisés ir pareigos naudojantis bendraja daline nuosavybe ir ją išlai-

30 Dabartinés lietuvių kalbos žodynas. 6-as leidimas. Vyr. red. S. Keinys. Vilnius: Lietuvių kalbos institutas, 2006 [interaktyvus]. 2011, 3-ias elektroninis leidimas <http://dz.lki.lt $>$.

31 Lietuviu kalbos žodynas (t. I-XX, 1941-2002). Redaktorių kolegija Naktinienè, G. (vyriausioji redaktorè), et al. [interaktyvus]. $2005<\mathrm{http}$ ://www.lkz.lt/dzl.php?12>.

32 Lietuvos Respublikos baudžiamasis kodeksas, supra note 27, 24 str.

33 Ibid., 25 str. $1 \mathrm{~d}$.

34 Lietuvos Respublikos civilinis kodeksas, supra note 19, 4.72 str. $2 \mathrm{~d}$.

35 Lietuvos Respublikos baudžiamojo proceso kodeksas. Vilnius: Registrų centras, 2012, 152 str. 2 d.

36 Goda, G., et al. Lietuvos Respublikos baudžiamojo proceso kodekso komentaras. Pirma knyga. Vilnius: Teisinès informacijos centras, 2003, p. 384.

37 Klimavičius, J. Ar taisyklingas bendrasavininkis? Gimtoji kalba. 2007, 6: 9-10.

$38 \quad$ Ibid. 
kant $^{39}$; Bendraturčio dalies bendrojoje jungtinejje nuosavybejje dydis nustatomas bendratučiu susitarimu ${ }^{40}$.

Bendrasavininkị taiso „Terminologijos taisymai“, siūlydami jo vietoj du pakaitus: dvižodị terminą nuosavybès bendrininkas ir vienažodi - bendraturtis ${ }^{41}$. Kalbant apie bendrasavininkị pravartu pažiūrèti ir ì „Kalbos praktikos patarimus“. Čia rašoma, kad nevartojami „<...> asmenis reiškiantys sudurtiniai daiktavardžiai su pirmuoju dèmeniu bendr- ir antruoju priesaginiu dèmeniu“ ir pateikiama administracinei kalbai būdingų tokiu būdu sudarytų dūrinių ir jų taisymų: bendranuomininkas, bendranuomininkis (= bendranuomis), bendrakaltininkas, bendrakaltininkis (= bendrakaltis), bendraskolininkas (= bendraskolis) ${ }^{42}$. Nors tarp taisinių bendrasavininkio ir nèra, matome, kad vartosenai neteiktini tokie sudurtiniai žodžiai, kurių antrieji dèmenys yra priesagą -ininkas turintys vediniai. Bendrasavininkis yra sudarytas su tokiu priesaginiu vediniu. Patarimuose teikiamų vartoti terminų antruoju dèmeniu eina žodis, kuriuo pasakoma, kas yra bendra: nuoma, kalte, skola. Taip sudarytas ir bendraturtis (: bendras + turtas). Bendraturti ir bendraskoli administracinė kalba prièmè. Pavyzdžiui: Jeigu skolininkai yra du ar daugiau asmenų (bendraskoliu), tai $\langle\ldots\rangle^{43}$. Kazimiero Gaivenio knygoje „Lietuvių terminologija: teorijos ir tvarkybos metmenys" rašoma, kad terminas bendraskolis buvo pateiktas ekonomisto L. Dargio ir kalbininko A.Salio sudarytame ir 1938 m. „Tautos ūkio“ žurnale paskelbtame „Prekybinès korespondencijos žodynèlyje $e^{44}$. Bendraskolis yra ir „Lietuvių kalbos žodyne“.

Taisant netinkamai sudarytus dèmenị bendr-turinčius dūrinius kalbos praktikos darbuose atkreipiamas dèmesys, kad bendrinèje kalboje tokie žodžiai negali turèti kitokių galūnių, išskyrus -is, $-\dot{e}^{45}$. Administracinejje kalboje ne visada laikomasi šio reikalavimo. Pavyzdžiui, Baudžiamojo kodekso komentaro abėcèlinèje dalykinè rodykleje vartojama vardininko forma bendraautorius ${ }^{46}$, o kitur tekste - norminè forma bendraautoris: <...> jis nèra kūrinio autorius (bendraautoris) ${ }^{47}$.

Vartojant tokius dūrinius reikia žiūrèti ne tik jų vardininko, bet ir kitų linksnių galūnių taisyklingumo. Termino bendraautoris formos negali turèti tokių galūnių, kokias turi terminas autorius, todèl bendrinei kalbai nepriimtinas dvejopai vartojamas įnagininkas: Tai, kas <...> priverté literatūros, mokslo, meno ar kitokio kūrinio ar jo dalies autoriu pripažinti kita asmenị bendraau toriumi <...> baudžiamas ${ }^{48}$;

39 Lietuvos Respublikos civilinis kodeksas, supra note 19, 4.76 str.

$40 \quad$ Ibid., 4.89 str. 2 d.

41 Terminologijos taisymai, supra note 29, p. 25.

42 Kalbos praktikos patarimai. Sudarè Pupkis, A. Vilnius: Mokslas, 1985, p. 283.

43 Lietuvos Respublikos civilinis kodeksas, supra note19, 6.5 str.

44 Žr. Gaivenis, K., supra note 5, p. 69-70.

45 Terminologijos taisymai, supra note 29, p. 24; Kanceliarines kalbos patarimai, supra note 25, p. 56.

46 Abramavičius, A., et al., supra note 28, p. 543.

47 Ibid., p. 399.

48 Lietuvos Respublikos baudžiamasis kodeksas, supra note 27, 191 str. 2 d. 
$<\ldots>$ privertimas kūrinio autoriu pripažinti kita asmenị bendraautorium $i^{49} ;<\ldots>$ pripažinti kita asmenị bendraau toriu ar autoriaus teisiu perèmeju $<\ldots . .>^{50}$ Bendraautoris turi būti linksniuojamas taip: bendraautoris, bendraautorio, bendraautoriui, bendraautori, bendraautoriu, bendraautoryje ir t. t. Pasitikrinti, ar pasirinktos žodžio formos yra taisyklingos, galima ir lyginant: bendraturtis - bendraturčio, su bendraturčiu, bendraieškis - bendraieškio, su bendraieškiu, tai ir bendraautoris - bendraautorio, su bendraautoriu.

Sutikdami su tuo, kad administracinè kalba yra bendrinės kalbos dalis, turime sutikti ir su tuo, kad visos jos sritys turi paklusti taisyklingos bendrinès kalbos reikalavimams, o kalbant apie jos terminų darybą - bendrinès kalbos žodžių darybos désniams. Vartojant ydingai sudarytus dèmenị bendr-turinčius terminus kenkiama administracinès kalbos taisyklingumui. Juolab kad darybos galimybės leidžia nevartoti nenorminių dūrinių. Tokiais atvejais nevertètų daryti jokių išlygų.

\section{Išvados}

Darant sudurtinius asmenų pavadinimus, visais įmanomais atvejais reikia laikytis bendrinès kalbos dūrinių darybos tradicijos, kuri rodo, kad sudurtinius žodžius kur kas labiau ịprasta daryti iš paprastųjų žodžių negu iš vedinių ar dūrinių. Taip pat svarbu, kad pasidaryti dūriniai turètų bendrinès kalbos dūriniams būdingą reikšmę.

Administracinëje kalboje vartojami sudurtiniai demenį bendr-turintys asmenų pavadinimai sudaryti dviem būdais. Vyrauja iš būdvardžio bendras ir daiktavardžio sudaryti terminai, pavyzdžiui: bendraturtis, bendrasavininkis, bendravykdytojas. Tik vienas terminas - bendraieškis - yra padarytas iš būdvardinio prieveiksmio bendrai ir veiksmažodžio.

Bendrinės lietuvių kalbos taisyklingumo reikalavimus atitinka be priesagų sudaryti antrąji daiktavardinès kilmès demenį turintys administraciniai terminai bendraturtis, bendrakaltis, bendraskolis. Antrieji terminų dėmenys yra daiktavardžiai, kuriais pasakoma, kas su kuo yra bendra. Tokią reikšmę turi bendrinès kalbos dūriniai, sudaryti su dèmeniu bendr- (bendradarbis, bendramokslis ir t. t.). Vengiant dūrinių, kurių antrasis dèmuo yra priesaginis žodis, neišsiverčiama be bendraautorio.

Terminas bendraieškis sudarytas su veiksmažodiniu dẻmeniu (bendrai $+i e s ̌ k o)$. Remiantis šiuo pavyzdžiu galima pasidaryti terminą bendravykdis ir vartoti ji vietoj kalbos taisyklingumo reikalavimų neatitinkančio bendravykdytojo, bendraatsakovi taip pat reiketų keisti veiksmažodinị demenị turinčiu bendaatsakiu.

Administracinei kalbai reikalingi dèmeni bendr-turintys asmenų pavadinimai gali būti sudaromi laikantis sudurtinių žodžių darybos tradicijos, todèl nèra būtinybès vartoti nenorminių dūrinių. Būtina tinkamai vartoti visas dūrinių formas. Ne tik 
jų vardininkas bendinėje kalboje turi turèti taisyklingas galūnes: vyriškosios giminès -is ir moteriškosios giminès - $\dot{e}$. Taisyklingumo reikalavimų reikia paisyti vartojant visas žodžio formas. Pavyzdžiui, vietoj vardininko bendraautoris ir inagininko bendraautoriu administracineje kalboje nereikia vartoti bendraautorius ir bendraautoriumi.

\section{Literatūra}

Abramavičius, A. et al. Lietuvos Respublikos baudžiamojo kodekso komentaras. Antra knyga. Specialioji dalis. Vilnius: Teisinès informacijos centras, 2004.

Būda, V. P. Ar vartotinas bendraatsakovas? Gimtoji kalba. 1995, 1.

Dabartinès lietuviu kalbos gramatika. Ambrazas, V., et al. Ketvirtoji pataisyta laida. Vilnius: Mokslo ir enciklopedijų leidybos institutas, 2005.

Dabartines lietuviu kalbos žodynas. 6-as (3-ias elektroninis) leidimas. Vyr. red. Keinys, S. Vilnius: Lietuvių kalbos institutas, 2006; [interaktyvus]. 2011<http:// dz.lki.lt $>$.

Gaivenis, K. Lietuviu terminologija: teorijos ir tvarkybos metmenys. Vilnius: Lietuvių kalbos instituto leidykla, 2002.

Goda, G., et al. Lietuvos Respublikos baudžiamojo proceso kodekso komentaras. Pirma knyga. Vilnius: Teisinès informacijos centras, 2003.

Kalbos praktikos patarimai. Sudarè Pupkis, A. Vilnius: Mokslas, 1985.

Kanceliarinès kalbos patarimai. Parengè Kniūkšta, P. Vilnius: Mokslo ir enciklopedijų leidykla, 1993.

Kanceliarinés kalbos patarimai. 5-asis leidimas. Parengè Kniūkšta, P. Vilnius:
Mokslo ir enciklopedijų leidybos institutas, 2002.

Keinys, S. Lietuviy terminologijos raida. Vilnius: Lietuvių kalbos instituto leidykla, 2012.

Klimavičius, J. Ar taisyklingas bendrasavininkis? Gimtoji kalba. 2007, 6.

Lietuviu kalbos žodynas (t. I-XX, 19412002). Redaktorių kolegija Naktinienè, G.(vyriausioji redaktorè), et al. [interaktyvus]. $2005<$ http://www.lkz.lt/dzl. php?12>.

Lietuvos Respublikos administraciniu teises pažeidimu kodeksas. Vilnius: Registrų centras, 2012.

Lietuvos Respublikos baudžiamasis kodeksas. Vilnius: Mūsų Saulužè, 2007.

Lietuvos Respublikos civilinis kodeksas. Vilnius: Registrų centras, 2012.

Lietuvos Respublikos civilinio proceso kodeksas. Vilnius: Registrų centras, 2012.

Mikelènas, V., et al. Lietuvos Respublikos civilinio kodekso komentaras. Antroji knyga. Vilnius: Justitia, 2004.

Pupkis, A. Kalbos kultūros studijos. Vilnius: Gimtasis žodis, 2005.

Terminologijos taisymai. Parengè Gaivenis, K., et al. Vilnius: Mokslas, 1992. 


\title{
FORMATION PECULIARITIES OF TERMS CONTAINING COMPONENT BENDR-IN ADMINISTRATIVE LANGUAGE
}

\author{
Laima Pečkuvienè \\ Mykolas Romeris University, Lithuania
}

Summary. Terminology is the core of any part of language. This article aims at analyzing terms containing the component bendr-, which are common in the Law Codes of Lithuanian Republic and their comments. The analysis of the Codes and their comments allows concluding that the terms in administrative language are formed in different ways and they do not always correspond to the requirements of the appellative grammar. For instance, the words bendrasavininkis and bendravykdytojas contain uncommon components.

It is essential to follow the traditions of general language in creating compound personal names, which claims that it is common to use ordinary words. This rule is valid for components containing suffixes which do not appear in the final term. It is important for them to contain typical meanings.

In the administrative language, terms with bendr-should correspond to the adjective bendras or adverb bendrai, according to the formation rules.

Administrative terms bendraturtis, bendrakaltis and bendraskolis conform to the component bendr-. Other components are the nouns that point out what is common in all cases.

The term bendraieškis (bendrai + ieško) is formed by the means of verbal component. Similarly, the term bendravykdis should be formed and used instead of the bendravykdytojas which does not conform to the grammaticality requirements. Moreover, bendraatsakovi should be replaced by the bendaatsakiu. In the administrative language, it is necessary to use all available variants and to dispose of faulty terms.

When assessing administrative terms in the terms of accepted norms, it is necessary to discriminate when the deviation from the general language is an unavoidable necessity needed to satisfy the usage needs.

Keywords: standard Lithuanian, administrative language, derivatives, compound words, word building elements.

Laima Pečkuvienè, Mykolo Romerio universiteto Politikos ir vadybos fakulteto Filosofijos ir humanistikos instituto lektorè. Mokslinių tyrimų kryptys: administracinès kalbos terminų daryba, gramatinès formos.

Laima Pečkuvienė, Mykolas Romeris University, Faculty of Politics and Management, Institute of Philosophy and Humanities, lecturer. Research interests: administrative language terms building, grammar forms. 